\title{
TO BE OR NOT TO BE: THE CONSTITUTIONAL QUESTION OF THE CALIFORNIA ABORTION LAW
}

In People v. Belous, ${ }^{1}$ the California Supreme Court voided the state's criminal abortion statute, repealed in $1967,{ }^{2}$ which provided that:

Every person who provides, supplies, or administers to any woman, or procures any woman to take any medicine, drug, or substance, or uses or employs any instrument or other means whatever, with intent thereby to procure the miscarriage of such woman, unless the same is necessary to preserve her life, is punishable by imprisonment in the State prison not less than two years nor more than five years. ${ }^{3}$

After a jury trial, the defendant, Dr. Leon Belous, a doctor of high professional repute, ${ }^{4}$ was convicted of abortion under this statute and conspiracy to commit abortion. Dr. Belous had referred a prosecution witness, Cheryl, to a doctor from Mexico who was practicing in the United States without a license, for an abortion which Dr. Belous refused to perform himself. In his defense, the doctor testified that he had acted "in response to [Cheryl's] pleadings," and with the belief that she and her boyfriend "would, in fact, do anything to terminate the pregancy which might involve butchery in Tijuana or self mutilation . . . The Doctor believed that if the young couple carried out their threats, Cheryl's very life was in danger." 5

The conviction of Dr. Belous was reversed when the California Supreme Court concluded that the statute was not "susceptible of a construction that does not violate legislative intent and that is sufficiently certain to satisfy due process requirements without improperly infringing on fundamental constitutional rights." 6 In reaching this conclusion, the court first examined the individual words of the statute and decided that by themselves they had no clear meaning and thus were vulnerable to the charge of unconstitutional vagueness. The

171 Cal. 2d -, 458 P.2d 194, 80 Cal. Rptr. 354 (1969).

2 Ch. 528, § 1, [1935] Cal. Stats. 1605, as amended, Cal. Penal Code $\$ 274$ (West 1955). When the Therapeutic Abortion Act, Cal. Health \& Safety Code \$\$2595054 (West Supp. 1968), was adopted in 1967, \$274 was amended to provide that abortions were illegal unless performed in compliance with the Therapeutic Abortion Act. 1955).

3 Ch. 528, § 1, [1935] Cal. Stats. 1605, as amended, Cal. Penal Code \$274 (West

4 Dr. Belous is a licensed doctor in California, on the staff of a Los Angeles hospital, a fellow of several medical societies, and a Director of the California Committee on Therapeutic Abortion. 71 Cal. $2 \mathrm{~d}$ at -458 P.2d at 195, 80 Cal. Rptr. at 355.

5 Id. at -, 458 P.2d at 196, 80 Cal. Rptr. at 356.

B Id. at -, 458 P.2d at 197, 80 Cal. Rptr. at 357. 
court then rejected various meanings which were offered to make the language sufficiently clear. It concluded that this finding was further supported because the statute delegated to the doctor, an interested party, the power to determine whether a woman has a right to an abortion.

This response was well attuned to current liberalization of both thought and practice regarding abortion law reform. Accordingly, the decision brings the law into a more realistic relationship with predominant social mores and beliefs. However, this writer believes that because of the court's reasoning in reaching this result, such action was not a proper judicial role, and that even if it were, the California court failed to provide sound reasoning to support its result.

\section{UNCONSTITUTIONAL VAGUENESS}

In attempting to define the phrase "necessary to preserve . . . life," the California Supreme Court first examined the isolated words of the statute, and concluded that no clear meaning of "necessary" and "preserve" could be ascertained. " It is not surprising that a seriatim examination of the words convinced the court that the phrase was vague. Necessity is a relative concept and must refer to a particular object to be meaningful. Nor can the word "preserve" be understood out of context. In the abstract, such words are not just vague, they are meaningless. ${ }^{8}$ Taken in context, however, these words do have meaning. The object of the necessity in this statute is "to preserve life." The term is defined by its object-life. Accordingly, the statute was intended to permit abortion only when the alternative was death.

The conclusion that this was the intended meaning is supported by an examination of various historical writings. Although early English law condemning abortion made no exception for the mother's safety, ${ }^{9}$ the priority of the mother's life over the foetus's was not a novel idea when California enacted its abortion statute in 1850. Medical, legal, and ecclesiastical writings reveal an impressive history of familiarity with the concept of preference for the mother's life.10

7 Id. at -, 458 P.2d at 198, 80 Cal. Rptr. at 358.

8 "Abstraction was the Jacob's ladder by which the philosopher ascended to certainty. The further he was from the facts, the nearer he thought himself to the truth." "F. LANGe, 1 History of Materialism 75 (1887), cited in J. Frank, Law AND THE MODERN Mínd 64 (1963).

9 Cf. Means, The Law of New York Concerning Abortion and the Status of the Foetus, 1664-1968: A Case of Cessation of Constitutionality, 14 N.Y.I.F. 411, 41922 (1968).

10 The Talmud mentions abortion only once and declares that "If a woman is in hard travail and her life cannot otherwise be saved, one cuts up the child within her womb and extracts it member by member because her life comes before that of the child." TALMUD, Tohoroth, Oholoth 7:6.

In fourth century Rome, Priscianus, a doctor and scholar, wrote:

No one has the right to prescribe any means for producing an abortion. A physician should not burden himself with this sin. Only where the uterus is diseased or where the mother is exposed for other reasons to danger through pregnancy, is an abortion permissible .... Just as it is sometimes of advan- 
Further support is also provided by a comparison with the statutes of other jurisdictions which have broadened the exception to permit abortions necessary to preserve "health." 11 The broader statutes were undoubtedly intended to prevent the harsh results caused by California's requirement that life itself must be at stake.

The court recognized that if a sufficiently specific interpretation of the words could be adopted, the statute could be saved, ${ }^{12}$ but it rejected all the suggested meanings, including the construction that life itself must be at stake. Nevertheless, it appeared to assume that this interpretation would be sufficiently certain. ${ }^{13}$ Judicial history warrants this assumption.

Throughout the nineteenth and twentieth centuries, courts have dealt with the "necessary to preserve" standard in abortion cases with relative ease. ${ }^{14}$ Only two related issues were ever seriously litigated:

tage to remove the dry twigs of a tree in order to save the whole tree or as a heavily laden ship may find it necessary in a storm to throw overboard some of its cargo in order to prevent a shipwreck.

F. Taussig, Abortion Spontaneous and Induced 277 (1936). Taussig also cites an eighteenth century physician who claimed that

where it is certainly known that a mature child cannot possible be delivered in the ordinary way alive, would it not be consistent with reason and conscience, for the preservation of the mother, as soon as it conveniently can be Id. done, by artificial modus to attempt to produce an abortion?

The French historian Le Foyer noted that thirteenth century French canonists also contemplated voluntary abortion to save the mother's life. LE FOYER, EXPOSÉ DU DroIt PÉnal Normand AU XIII Siêcle 74 n.3 (1931), cited in Davies, The Laze of Abortion and Necessity, 2 Mod. L. REv. 126, 137 n.47 (1938).

In 1844, the Report of the Massachusetts Criminal Law Commissioners on Abortion stated that abortion in order to save the woman's life was legally justified. H. Storer \& F. Heard, Criminal Abortion $187 \mathrm{n} .2$ (1868) [hereinafter cited as STORER]. Similarly, in Great Britain the Criminal Law Commissioners advised in 1846 that an "expedient" exception for saving the mother's life be added to the British abortion law. Great Britain Ministry of Healte and Home OFFICE, Report OF THE INTER-DepartMental Commission ON ABORTION 29 (1939).

A medical treatise of 1845 affirms that

[t]he medical man is clearly justified in resorting to any measures which promises to preserve the life of mother and child when both are threatened; and where one only can by any possibility be preserved, the female herself may use her right of self-preservation, and choose whether her own life or that of her child shall fall a sacrifice to the means recommended to be used.

W. Guy, Princtples of Forensic Medictne 145 (1845) ; cf. J. Wharton, The Laws RELATING to tHE WoMEN OF ENGLANd 155 (1853).

The California statute was preceded by those of New York (1828), Maine (1840), Ohio (1841), and Virginia (1848). D. Granfiesd, THe Abortion Decision 79 (1969) [hereinafter cited as GRANFIELD].

11 See, e.g., D.C. Code ANN. \$\$22-201 (1967). This statute was declared unconstitutionally vague in United States v. Vuitch, 305 F. Supp. 1032 (D.D.C. 1969). The opinion deals primarily with the vagueness of "preservation of health."

12 See 71 Cal. 2d at -, 458 P.2d at 198, 80 Cal. Rptr. at 358.

$13 \mathrm{Id}$. at -, 458 P.2d at 198-200, 80 Cal. Rptr. at 358-60.

14 The following random sampling of abortion cases indicates the wide understanding and usage of the exception to preserve or save the mother's life: People v. Gallardo, 41 Cal. 2d 57, 257 P.2d 29 (1953); State v. Lee, 69 Conn. 186, 37 A. 75 (1897) ; State v. Quinn, 18 Del. 339, 45 A. 544 (1899); Beasley v. People, 89 Ill. 571 (1878); Willey v. State, 52 Ind. 246 (1875); State v. Leeper, 70 Iowa 748,30 N.W. 501 (1886); Commonwealth v. Brunelle, 341 Mass. 675, 171 N.E.2d 850 (1961); State v. Meek, 70 Mo. 355, 35 Am. R. 427 (1879); State v. Cooper, 22 N.J.L. 52, 51 Am. 
(1) whether the indictment for abortion sufficiently alleged the lack of necessity to preserve the mother's life, ${ }^{15}$ and (2) whether the state bore the burden of proving that the abortion was not necessary to preserve the mother's life. ${ }^{16}$ The most widely accepted rule places the burden on the state to negate necessity, ${ }^{17}$ but evidence that the woman is normal and in good health adequately refutes the claim that bearing a child would threaten her life. Medical evidence alone could prove or disprove necessity. ${ }^{18}$ It was understood by courts, juries, and doctors that suicide, a concomitant threat to life, ${ }^{19}$ extreme emotional distress, or social or economic considerations ${ }^{20}$ were not acceptable justifications for the abortion. In fact, the medical profession itself originally defined the exception so narrowly that only when deformity of the pelvis would

Dec. 248 (1849) ; State v. Beylea, 9 N.D. 353, 83 N.W. 1 (1900) ; Moody v. Ohio, 17 Ohio St. 110 (1866); State v. Buck, 200 Ore. 87, 262 P.2d 495 (1953) ; State v. St. Angelo, 72 R.I. 412, 52 A.2d 513 (1947); State v. Wells, 35 Utah 400, 100 P. 681 (1909).

15 See, e.g., State v. Quinn, 18 Del. 399, 45 A. 544 (1899) ; State v. Leeper, 70 Iowa 748, 30 N.W. 501 (1886).

16 See, e.g., People v. Gallardo, 41 Cal. 2d 57, 257 P.2d 29 (1953) ; State v. De Groat, 259 Mo. 364, 168 S.W. 702 (1914); Moody v. Ohio, 17 Ohio St. 110 (1866); State v. St. Angelo, 72 R.I. 412, 52 A.2d 513 (1947).

17 See, e.g., People v. Gallardo, 41 Cal. 2d 57, 257 P.2d 29 (1953); People v. Schultz-Kuighten, 277 I11. 238, 115 N.E. 140 (1917); State v. De Groat, 259 Mo. 364, 168 S.W. 702 (1914); Moody v. Ohio, 17 Ohio St. 110 (1866); State v. St. Angelo, 72 R.I. 412, 52 A.2d 513 (1947). But see Williams v. United States, 138 F.2d 81 (D.C. Cir. 1943).

18

The fact that an operation was not necessary to preserve life may be shown by evidence that the woman was in good health before the operation, and her testimony as to her physical condition is sufficient on this issue.

People v. Gallardo, 41 Cal. 2d 57, 62, 257 P.2d 29, 32 (1953).

The authorities are to the effect that when it is shown that the woman was healthy and in a normal condition ... the evidence is sufficient to raise the inference and to find the fact that the production of the miscarriage was not necessary to save the woman's life ....

State v. Wells, 35 Utah 400, 407, 100 P. 681, 686 (1909). See also State v. Dunklebarger, 206 Iowa 971, 976-77, 221 N.W. 592, 594 (1928) (evidence of blood poisoning, discharge and inflammation indicated necessity) ; Wells v. Insurance Co., $191 \mathrm{~Pa}$. 207, 212-13, 43 A. 126, 127 (1899); Murphy v. Board of Medical Examiners, 75 Cal. App. 161, 166-67, 170 P.2d 510, 513 (1946); People v. Smitherman, 58 Cal. App. 121, 123, 135 P.2d 674, 675 (1943).

19 It is very manifest that the statute was not intended to apply to such a case [of threatened suicide], but only to a case where the death of the mother can reasonably be anticipated to result from natural causes unless the child is destroyed.

Hatchard v. State, 79 Wis. 357, 362, 48 N.W. 380, 382 (1891).

In this context it is interesting to note that "there is good evidence that the suicide rate among the pregnant is considerably lower than among the general population of non-pregnant women." Niswander, Medical Abortion Practices in the United States, in ABORTION AND THE LAW 53 (D. Smith ed. 1967). See also GRANFIELD 104-05.

20 Abortion is criminal even though "animated only by kindly motives" when it is "not in fact necessary to save the life of the woman." State v. Belyea, 9 N.D. 353, 361,83 N.W. 1, 3 (1900). A physician must not be influenced by the woman's adjurations, economic considerations, or sympathy for the girl threatened with social ruin. G. RIDDELL, ABORTION AND MATERNAL MORTALITY 22 (1931); cf. Williams v. United States, 138 F.2d 81 (D.C. Cir. 1943). See also F. Wharton \& M. StrLLE, 3 Medical
Jurisprudence, 54-59, 67-69 (4th ed. 1884). 
preclude natural delivery of a mature child was abortion permissible. ${ }^{21}$ Through the years the courts have not, however, restricted the standard of necessity to this sole exception and have assimilated other medical conditions into this category.

Doubtless, careful scrutiny of the abortion statutes is required because of the substantial penalties which may be visited upon a doctor. Nevertheless, the harshness of the penalties is not itself a reason to find a statute unconstitutionally vague. ${ }^{22}$ The test remains whether the statute has adequately circumscribed the prohibited behavior. ${ }^{23}$ The fact that a consistent standard of medical evidence has been applied by the courts for over a century to determine the legality of an abortion ${ }^{24}$ is strong evidence that in practice the terms do have administrable meaning. ${ }^{25}$ Although

there may be marginal cases in which it is difficult to determine the side of the line on which a particular fact situation falls, this is not sufficient justification to hold the language too ambiguous to define a criminal offense. ${ }^{26}$

The only appreciable degree of uncertainty in the statute results from the variability in judgment among doctors. ${ }^{27}$ Each must decide in good faith if abortion is necessary to preserve the life of the mother; if his estimate is inconsistent with that of a jury, he may be convicted of unlawful abortion. But the void-for-vagueness doctrine is not a jury corrective. Since juries must appraise novel fact situations in relation

21 F. Ogston, Lectures on Mentcal Jurisprudence 193 (1878); F. Wharton \& M. STILLE, supra note 20 , at 7.

22 See Barsky v. Board of Regents, 347 U.S. 442, 448 (1953).

23 Roth v. United States, 354 U.S. 476, 491 (1956).

24 Today, all states permit abortion when necessary to save the mother's life. GRANFIELd 81 .

In State v. Moretti, 52 N.J. 182, 244 A.2d 499 (1968), the court held that the phrase "lawful justification" in the New Jersey, abortion statute was not vague if restricted to the necessity to preserve the mother's life. Id. at 191, 244 A.2d at 504 . See also State v. Buck, 200 Ore. 87, 93, 262 P.2d 495, 497-98 (1953).

On the basis of judicial experience with the doctrine, the Supreme Court of Massachusetts has recently held that the term "unlawfully," as used in the state abortion statute,

has been made sufficiently definite by decisions of this court. In our cases it has been stated over the years that a physician may lawfully perform an abortion if he acts in good faith and in an honest belief that it is necessary for the preservation of the life or health of the woman.

Kudish v. Board of Registration, - Mass. -, -, 248 N.E.2d 264, 266 (1969).

$25 \mathrm{See}$, e.g., cases cited note 18 supra.

28 United States v. Petrillo, 332 U.S. 1 (1946). The Supreme Court has also affirmed the principle that if a "general class of offenses can be made constitutionally definite by a reasonable construction of the statute, this Court is under a duty to give the statute that construction." United States v. Harriss, 347 U.S. 612, 618 (1954).

27 The doctor's good faith belief that the abortion was necessary generally provides a defense. See, e.g., State v. Dunklebarger, 206 Iowa 971, 979-80, 221 N.W. 592 (1928); Commonwealth v. Wheeler, 315 Mass. 394, 395, 53 N.E.2d 4 (1944). However, it is clear that his judgment must rely on medical factors. 
to a given legislative rubric, no defense is immune from ambiguity insofar as it is subject to their appraisal..$^{28}$

The conclusion that the statute, as interpreted by the California courts, gives sufficient notice of the conduct it prohibits is also supported by comparison with the class of homicide cases in which a defendant pleads that his act was necessary to preserve the life of another. ${ }^{29}$ The defense is available to the defendant who can show that a serious danger to another's life was imminent, though not immediate, and highly probable, though not certain. ${ }^{30}$ Here too, the jury must evaluate the defendant's judgment, notwithstanding that it is often made under circumstances of greater complexity ${ }^{31}$ and stress than in an abortion case.

For instance, the abortionist has more time for reflection than does the homicide defendant claiming the defense of necessity. The latter must make an immediate decision whether to take the life of the attacker in order to save the life of the victim, while the abortionist has days or perhaps weeks to deliberate and seek advice on his decision. Moreover, the homicide defendant may have before him a less clear set of priorities. If both the attacker and the victim are related to him, his instincts of attachment may be equivocal. Accordingly, he is put to the hard choice of choosing between the lives of two independently existing persons both of whom have substantial emotional claims on him. To the physician, on the other hand, it is clear before parturition that the foetus has fewer human attachments and dependents than has the mother. Thus he has a more objective standard by which to measure the relative worth of the lives of the mother and foetus, whether or not one believes that use of such a standard is morally tolerable.

Society has accepted the concept of necessity in homicide cases where the penalty and social stigma for an incorrect evaluation are

${ }^{28}$ Cf. United States v. Petrillo, 332 U.S. 1, 7 (1946).

29 Cal. PenaI Code $\$ 197$ (West Supp. 1968), which is representative of state statutes dealing with noncriminal homicide, provides that:

Homicide is also justifiable when committed by any person in either of the following cases:

3. When committed in the lawful defense of such person, or of a wife or husband, parent, child, master, mistress, or servant of such person when there is reasonable ground to apprehend a design to commit a felony or to do some great bodily injury, and imminent danger of such design being accomplished ....

A concise discussion of common law sources discussing the defense of necessity is found in Regina v. Dudley \& Stephens, 14 Q.B.D. 273 (1884) in which Lord Coleridge rejected the defense.

30 See, e.g., People v. Holt, 25 Cal. 2d 59, 153 P.2d 21 (1944) ; People v. Dawson, 88 Cal. App. 2d 85, 198 P.2d 338 (1948) ; People v. Toledo, 85 Cal. App. 2d 577, 193 P.2d 953 (1948). Thus, some degree of indefiniteness has been accepted in abortion cases.

31 The opinion of Lord Coleridge in Regina v. Dudley \& Stephens, 14 Q.B.D. 273 (1884), is illustrative of the complexities inherent in this social judgment.

It is not needful to point out the awful danger of admitting the principle which has been contended for. Who is to be the judge of this sort of necessity? By what measure is the comparative value of lives to be measured?

Id. at 287 . 
greater than in the abortion cases. To accept the concept in the more difficult homicide cases but not in the easier abortion cases seems inconsistent.

The court declined to accept the interpretation that an abortion is permissible only when the alternative is death, first on the ground that it had been "rejected by the courts of this state as not reflecting legislative intent . . . ."32 To establish this point, the court cited two lower court decisions. However, in one of these cases, People $v$. Arbanel, the court of appeals held that there was "a complete lack of proof of criminal intent," 33 not, as the Belous court claimed, that the mere possibility of suicide shows adequate necessity. ${ }^{34}$ People $v$. Ballard, ${ }^{35}$ the second case cited, is also rather weak support for the court's assertion. In Ballard, it was held that the evidence of the woman's condition did "not seem to prove beyond a reasonable doubt and to a moral certainty that she was in good health and that treatment of some sort was not necessary." ${ }^{38}$ Thus, the court concluded that the prosecution had offered no testimony to refute the doctor's assertion that the abortion was necessary within the meaning of the statute. ${ }^{37}$ The effect of the decision is merely to put the burden of proof upon the prosecution to establish lack of necessity once the defense is raised.

But in any case, these decisions are not binding authorities vis-àvis the California Supreme Court. The court has, in effect, stated that its decision to invalidate the statute for vagueness was compelled by decisions of inferior tribunals within its jurisdiction. If the court intended to save the statute, opinions of the lower courts, however interpreted, should be no bar. While it may be appropriate to inquire into what the lower courts have said, the significant issue is whether they were correct.

\section{Constitutional Rights to Life and to Bear Children}

A second reason offered by the Belous court for rejecting the "certainty" interpretation is that the high degree of necessity required

3271 Cal. $2 \mathrm{~d}$ at,$- 458 \mathrm{P} .2 \mathrm{~d}$ at 198-99, $80 \mathrm{Cal}$. Rptr. at 358-59.

33239 Cal. App. 2d 31, 35, 48 Cal. Rptr. 336, 339 (1965). The court held that a doctor's reliance upon the recommendations of psychiatrists that abortion was necessary to save the patient from the possibility of suicide was not consistent with a finding of criminal intent. Id. at 33, 48 Cal. Rptr. at 338. Since the state had failed to prove that the abortion was not performed to save the mother's life, the conviction was vacated.

A reading of the complete record persuades [us] that under the authority of People v. Ballard [167 Cal. App. 2d 803, 335 P.2d 204 (1959)] this judgment must be reversed, as it almost demonstrably appears that the jury found appellant guilty because they believed him to be a bad man rather than because he had committed an illegal abortion within the meaning of the law.

Id. at 35, 48 Cal. Rptr. at 339.

$3471 \mathrm{Cal} .2 \mathrm{~d}$ at -, 458 P.2d at 204, 80 Cal. Rptr. at 359.

35167 Cal. App. 2d 803, 335 P.2d 204 (1959).

36 Id. at 814,335 P.2d at 211 .

37 Id. at 814,335 P.2d at 212 . 
"would work an invalid abridgement of the woman's constitutional rights . . . ." ss The rights to which the court refers are her right to life and her right to choose whether to bear children.

\section{A. The Right to Life}

The argument that the statute violates a woman's right to life is not persuasive; protection of the woman's life is, of course, the sole exception to the statutory prohibition of all abortions. Nor must the doctor wait until the woman is on the verge of death before he can act; the threat to life which is a condition to a legal abortion can be one which is "delayed to a greater or less extent." 39 A woman's right to life does receive protection from the dangers of childbearing. ${ }^{40}$

The court apparently recognized that the certainty standard would provide some protection of the woman's right to life, but it went on to state:

We are also satisfied that the state may not require that degree of risk involved in respondent's definition, which would prohibit an abortion, where death from childbirth although not medically certain, would be substantially certain or more likely than not. ${ }^{41}$

However, this conclusion is not convincing.

Initially, it should be noted that the court recognized the possibility that the statute could be construed as requiring a "more probable than not" standard. Indeed, it was apparently the court's opinion that that was probably the original intention of the legislature. ${ }^{42}$ However, such an interpretation was rejected because the court thought that it was not reasonably suggested by the words themselves, nor had men of "uncommon intelligence" guessed at that meaning. ${ }^{43}$ After the court has stated that the relative safety test would be sufficiently certain to save it from constitutional attack, ${ }^{44}$ it is unclear why it is relevant that men of uncommon intelligence have not guessed at that meaning. Presumably, if that is the intended meaning and it is constitutional, it ought to be adopted. Moreover, the argument that the words do not suggest such a test seems strained. There does not appear to be any reason why a "more probable than not" standard could not be read into

3871 Cal. 2d at -, 458 P.2d at 199, 80 Cal. Rptr. at 359.

39 People v. Ballard, 167 Cal. App. 2d 803, 814, 335 P.2d 204, 212 (1959).

40 In making the argument that the statute abridged the woman's "right to life," the Belous court was apparently influenced by the statistics regarding the incidence and effect of criminal abortions. See $71 \mathrm{Cal}$. 2d at -, 458 P.2d at $201 \mathrm{nn} .9,10,80 \mathrm{Cal}$. Rptr. at $361 \mathrm{nn} .9,10$.

41 Id. at -, 458 P.2d at 203,80 Cal. Rptr. at 363.

42 Id. at,- 458 P.2d at 204, 80 Cal. Rptr. at 364. Specifically, the test would weigh the probability of death by abortion against the probability of death in childbirth.

43 Id. at -, 458 P.2d at 205, 80 Cal. Rptr. at 365.

44 Id. at -, 458 P.2d at 204, 80 Cal. Rptr. at 364. 
the words; had the court not been bothered by other aspects of the statute it might have done so.

More importantly, however, the court in rejecting the "certainty" standard overturned the balance struck by the legislature between the competing rights of the mother and foetus. The court seemed to deny that the legislature, in passing the abortion statute, intended to draw a line for the protection of human life. If, as this Comment will seek to show, that conclusion is wrong, the court's decision to upset the legislative resolution is improper.

\section{B. The Right to Bear Children}

The existence of a "right to decide whether to bear children" is open to question. The California court derived it from "the right to 'privacy' or 'liberty' in matters related to marriage, family and sex." 45 As authority, the court merely cited cases, without elaboration or explanation, which deduced a right to privacy from the fourth amendment prohibition of unreasonable searches, ${ }^{46}$ the equal protection clause, ${ }^{47}$ and first amendment rights. ${ }^{48}$ But these cases contain no more than dicta to support a right to bear children, much less a right to abortion. Moreover, while a right to privacy may be good constitutional law, the circumstances which no doubt prompted its derivation from the explicit words of the Constitution do not exist in the context of abortion laws. There is no "search of the sacred precincts of marital bedrooms" involved in discovering a violation of the abortion statute, ${ }^{40}$ no arbitrary discrimination among people, ${ }^{50}$ nor any invasion of freedom of speech

4571 Cal. 2d at $\rightarrow, 458$ P.2d at 199, 80 Cal. Rptr. at 359-60.

46 See Griswold v. Connecticut, 381 U.S. 479 (1965).

47 Loving v. Virginia, 388 U.S. 1 (1967); Skinner v. Oklahoma, 316 U.S. 535 (1942). In Loving, although the Court raised a due process issue in the final paragraph of the opinion, the decision was essentialy placed on the grounds of equal protection:

To deny this fundamental freedom on so unsupportable a basis as the racial classifications embodied in these statutes, classifications so directly subversive of the principle of equality at the heart of the Fourteenth Amendment, is surely to deprive all the State's citizens of liberty without due process of law. 388 U.S. at 12.

48 Pierce v. Society of Sisters, 268 U.S. 510 (1925); Meyer v. Nebraska, 262 U.S. 390 (1923).

49 Compare Griswold v. Connecticut, 381 U.S. 479 (1965).

00 It has been argued by some proponents of abortion law reform that the present abortion laws do discriminate against the poor. Referring to the hospital committee system of approving abortions, one author has commented that the

most disastrous result . . . has been the economic and social discrimination against one group-the ward patients. In large cities the poor, particularly Negroes and Porto Ricans, are virtually denied the same medical care as the privileged few ... In a survey of 60 leading hospitals across the country, the rate of abortions for private patients proved to be almost four times greater than for ward patients ....

L. LAdER, ABortion 29 (1966). Nevertheless, Lader admits that it is the fear of "religious and political pressure"-not the law-which has produced the inequities of the committee and quota system. Id. 29. It is apparent that the methods of hospital 
or religion. ${ }^{51}$ Conceivably one could look to the ninth amendment and classify it as a residual right, ${ }^{52}$ but there is very little precedent to support such a classification; nor does the California court make such an argument.

Nevertheless, even assuming that the right of privacy or the ninth amendment does provide a constitutional guarantee of the right to bear children, as the Belous court recognized, the question whether the abortion statute unconstitutionally interferes with this right remains unanswered. In attempting to answer this question, the court reasoned that (1) only a valid purpose will justify restriction of that right by the state; (2) the purpose of the statute when enacted in the nineteenth century was to protect the woman from the dangers of internal surgery; (3) this purpose is now invalid because it is medically safer to abort than to bear a child; and therefore (4) the statute has become unconstitutional, ${ }^{53}$ since there is no longer any countervailing state interest. Logical as this analysis may appear, its validity is compromised by the assumption of an essential, but unwarranted, premise, and by what this Comment asserts is the erroneous finding that the statute was not intended to accord rights to the foetus.

The court's assumption was equation of the right not to bear a child with the right to abort a foetus. Certainly, this equation is not compelled. The right to an abortion is not essential to exercise effectively the right not to have a child. One could conclude instead, for example, that the right may be exercised only by some form of birth control. Indeed, there is good reason to say that the question should not be made, since a foetus is a living thing, albeit not an independent one, that develops into a being to whom our society accords certain rights. That the abortion statute intended to protect these rights and to define the line for the protection of human life is crucial to the criticism of the court's opinion.

administration and the availability of ward services are largely responsible for this result. The equal protection argument was not raised in Belous.

See also ABORTION AND THE LAW, sipra note 19 , at $39-40,89-90 ; R$. Lucas, Federal Constitutional Limitations on the Enforcement and Administration of State Abortion Statutes, 46 N.C.L. REv. 730, 769-73 (1968).

51 It has also been argued that abortion laws are sponsored by the Catholic Church and therefore violate freedom of religion. See, e.g., ABORTION AND THE LAW, supra note 19 , at 231 ; LADER, supra note 50 , at 165 ; Lucas, supra note 50 , at 744 . However, it is clear that Catholics were not responsible for the original legislation, for they were simply not a major political force at the time. Quay, Justifiable Abortion-Medical and Legal Fonndations, 49 Grorgetown L.J. 395, 445 (1961). Today, the statistics collected by A. Rossi suggest that Catholics are not alone in resisting liberalization of abortion laws. A. Rossi, Public Viezes on Abortion, in The Case for Legalizen Abortion Now 40 (A. F. Guttmacher ed. 1967). It seems clear enough that abortion laws are the product of a Judaeo-Christian concept of life, supported, perhaps, by biological evidence. LADER, supra 50, at 23, 94.

52 Justice Goldberg, concurring in Griswold v. Connecticut, relied on the ninth amendment to protect "those liberties that are so rooted in the traditions and conscience of our people as to be ranked as fundamental." 381 U.S. at 487. The right to bear a child might be included therein, emanating from the "traditions and [collective] conscience of our people." "Id. at 493 (quoting Snyder v. Massachusetts, 291 U.S. 97, 105 (1933)).

5371 Cal. 2d at -, 458 P.2d at 200-02, 80 Cal. Rptr. at 359-62. 


\section{Protection of Human Life}

It is a basic concept of "ordered liberty" that boundaries of an individual's rights are drawn where they encounter the rights of another. ${ }^{54}$ Thus, if rights are ascribed to a living foetus, the mother's freedom to destroy it may be denied or curtailed. The issues which the California court failed to meet are whether society may ascribe rights to a foetus, and whether the California abortion statute did so. More simply, does the existence of a living foetus limit the mother's right not to bear a child?

These issues are further complicated by the impossibility of framing an answer in absolute terms. Rights may be gradually accorded to, and withdrawn from, an individual at various stages of maturity; the infant, for instance, is not treated as the equal of an adult. Furthermore, although certain rights cannot be enjoyed by the child until his birth, they accrue to him, in the sense that they can be enforced on his behalf, before then. ${ }^{55}$ In the eyes of the law "a child en ventre sa mère is to be considered a living thing . . . ." 56 It is therefore no answer to say, as the court did, that the law does not recognize the foetus as "equivalent to a born child." 57

At common law, the individual existence of the foetus was recognized and protected juridically only after "quickening," 58 a moment now deemed insignificant in foetal development by science and the law..$^{\mathbf{5 9}}$ But this does not confute the principle that the state has a compelling interest in protecting the life of any individual, and that it may choose the point at which it will assert this interest. Societies which have tolerated infanticide selected a point substantially after birth. ${ }^{60}$ Those

54 Cf. West Coast Hotel Co. v. Parrish, 300 U.S. 379, 391 (1937) ; Munn v. Illinois, 94 U.S. 113, 124 (1876); Ex Parte Drexel, 147 Cal. 763, 82 P. 429 (1905).

55 For an excellent discussion of the legal rights which accrue to the foetus before birth, see Louisell, Abortion, The Practice of Medicine and the Due Process of Lawe, 16 U.C.L.A. L. REv. 233, 235-244 (1969) ; cf. Note, The Impact of Medical Knowledge on the Laze Relating to Prenatal Injuries, 110 U. PA. L. Rev. 554 (1962).

See also Scott v. McPheeters, 33 Cal. App. 2d. 629, 634, 92 P.2d 678, 681 (1939).

56 In Hall v. Hancock, 32 Mass. (15 Pick.) 255, 258 (1837), the court further noted that the criminal law recognized the point of "quickening" as the beginning of life, in contrast to the civil law. The abandonment of that notion in abortion statutes has since eradicated the distinction between the concepts of life in the two fields.

5771 Cal. 2d at -, 458 P.2d at 202, 80 Cal. Rptr. at 362.

Furthermore, for at least some purposes, the foetus is treated like a born child. A California court recently refused to dismiss an indictment for murdering a foetus which was in the third trimester of pregnancy. Keeler v. Superior Court, - Cal. App. 2d -, 80 Cal. Rptr. 865 (1969).

58 "Life begins in contemplation of law as soon as an infant is able to stir in the mother's womb." 1 W. BLACKSTONE, COMMENTARIEs 129.

The word "foetus" is used in this Comment to mean human organism after conception and before birth.

69 The distinction was disavowed in the nineteenth century and has not been retained by any state's abortion statute. F. WhARTON, CRIMINAL LAW $\$ 1220$ (5th ed. 1861); J. ReEse, Medical JuRISPRudence 441 (1884); and StORER, supra note 10, at $1044,1144$.

60 Infanticide was practiced with indifference in Rome, for example, by exposure, drowning, and strangulation. J. NOONAN, CoNTRACEPTION 85-87 (1965). 
which condone parricide withdraw protection after a point is passed. ${ }^{01}$ The choice made by the California legislature was to extend its protection to a foetus after conception. In a purely biological sense, this was a rational judgment. In a social sense, it was a legislative evaluation directly related to the objective of protecting human life.

The Belous court denied the relevance of the issue by treating the statute as a device to protect a woman's health from dangerous abortive techniques. ${ }^{62}$ In so doing, it misread the intellectual and legal history of abortion legislation throughout the country. In fact, only one other court has described the abortion statute as a measure primarily "to guard the health and life of the mother against the consequences" of the operation. ${ }^{83}$ That statement is itself unconvincing when juxtaposed with the observation in the same opinion that the offense of the mother in submitting to abortion "is against the life of the child." 64 If the mother has offended against the life of the child by submitting to abortion, it is difficult to understand why the abortionist has not.

Further doubt is cast upon the analysis of the Belous court by comparing other judicial statements. In 1850, a Pennsylvania court wrote that the essence of the offense is

the destruction of gestation, by wicked means and against nature . . . B By the well-settled and established doctrine of the common law, the civil rights of an infant en ventra sa mère are fully protected at all periods after conception . . . . ${ }^{65}$

This view was adopted by the Colorado Supreme Court in $1909 .^{86}$ Likewise, an earlier New Jersey decision held that the offense of procuring abortion was, under common law, "an offence against life [of the child]." The crucial issue in that case was considered to be "whether the child be in esse, so that any crime can be committed against its person." ${ }^{67}$ Wisconsin expressed the same attitude by requiring for the criminal offense the "intent . . . to destroy such child." ${ }^{8}$ Thus, judicial history indicates that the crime of abortion is committed not merely against the health of the woman but against the foetus after the stage of its development designated by law,

61 P. FreUChen, Book of THE Eskimos 194-95 (1961).

$6271 \mathrm{Cal} .2 \mathrm{~d}$ at $-458 \mathrm{P} .2 \mathrm{~d}$ at 201-02, $80 \mathrm{Cal}$. Rptr. at 360-61. It is interesting to note that the court deals extensively with the dangers of surgery in the nineteenth century which, it claims, justified abortion laws at that time. Id. However, a modern authority states that "intra-uterine introduction of irritating substances to induce abortion rather than surgery is the most frequenly used single method for inducing criminal abortion." H. ROSEN, THERAPEUTTC ABORTION 8 (1964).

63 State v. Murphy, 27 N.J.L. 112, 114 (1858), reaffirmed by the same court in State v. Gredick, 43 N.J.L. 86,89 (1881), and Gleitman v. Cosgrove, 49 N.J. 22, 52, 227 A.2d 689, 705 (1967).

64 State v. Murphy, 27 N.J.L. 112, 114 (1858).

65 Mills v. Commonwealth, $13 \mathrm{~Pa} .630,632$ (1850). "It is a crime against nature, which obstructs the fountain of life, and therefore it is punished." Id. at 632 .

66 Marmaduke v. People, 45 Colo. 357, 361-62, 101 P. 337, 338 (1909).

67 State v. Cooper, 22 N.J.L. 52, 54, 51 Am. Dec. 248, 249 (1849).

68 Hatchard v. State, 79 Wis. 357, 360, 48 N.W. 380, 381 (1891). 
whether after the moment of "quickness," as provided under the common law, or after conception, as provided by statute. ${ }^{69}$

The medical profession agreed with this definition of abortion. The American Medical Association in 1859 unanimously adopted a resolution expressing their abhorrence of the practice of abortion "at every period of gestation" as an "unwarrantable destruction of human life," and added a prayer that the states strengthen their laws against the crime. ${ }^{70}$ Doctor Horatio Storer and Mr. Franklin Heard approvingly noted that this resolution "was sent to the legislatures of the several States. There is reason to believe that, directly and indirectly, it was productive of a great deal of good." 71

It is further apparent that legislatures enacting abortion statutes were moved by a concern for the morals of society. "If sexual pleasures could be indulged with impugnity," wrote one editorialist in 1832, "the bonds which hold society together would be broken asunder." 72 Criminal abortion, according to the Massachusetts Supreme Court in 1858, was "done with a wicked and base motive, offensive to good morals and injurious to society . . . ."73 These views comport well with the fact that all of these statutes were enacted in an era permeated by a highly moralistic temper. ${ }^{74}$ Nevertheless, though the articulation of these moral attitudes may be outdated today, the decision to protect life after conception cannot be dismissed as victorian prudery.

The California statute predated many of the foregoing comments, but it was no less representative of the concerns prevalent at the time. The penal code classified abortion as a crime "Against the Person and Against Public Decency and Good Morals," rather than a crime "Against the Public Health and Safety." 75 Individual doctors expressed repulsion for the mother's disregard of "life of the being within her." 78 "[T] $[T$ he killing of a foetus at any time before birth is as much murder as the killing of a child at any time after birth," another medical scholar wrote. ${ }^{77}$ Doctors displayed little or no concern for the

69 State v. Murphy, 27 N.J.L. 112, 114 (1858). This court stated that the abortion statute was enacted to protect the health and life of the mother, thereby filling the gap in the common law.

70 STORER, supra note 10, at $135 \mathrm{n} .1$.

71 Id. 147 n.1.

72 Note, A Functional Study of Existing Abortion Lawes, 35 Colum. L. Rev. 86, 93 n. 39 (1935) (quoting 2 LEG. EXAM. 10 (1832)).

73 See L. LADER, supra note 50, at 89-92 (1966); cf. STORER, supra note 10, at 14, 60-64, 103, 134.

74 Commonwealth v. Wood, 77 Mass. (11 Gray) 85, 89-90 (1858).

75 Cal. Penal Code tits. 9, 10 (West 1955). Title 9 includes crimes against the person, public decency, and good morals; title 10 includes offenses against public health and safety. Abortion, $\$ \$ 274-75$, falls within title 9, along with rape, carnal abuse of children, bigamy, incest, and indecent exposure. 1884).

$7^{76} 3$ F. Wharton \& M. Stillie, Medical Jurisprudence 54-59, $67-69$ (4th ed.

$77 \mathrm{H}$. Chaparan, Medical Jurisprudence, Insanity \& Toxicology 173 (3d ed. 1903) (citing from an 1854 speech at the University of Pennsylvania entitled On Criminal Abortion by H. Hodge). 
hazards of abortion to the health of the mother, but worried greatly over her morals and the life of the child. Given that climate of opinion at the time abortion statutes were enacted, it is not correct to conclude, as did the Belous court, that "considerations of the woman's health" were the primary motivations for the legislation. ${ }^{78}$

Nor can it be maintained that a desire to protect the beginning of human life is no longer a valid reason for upholding the constitutionality of abortion statutes. Modern courts also acknowledge a legislative intent to protect the foetus. The Oregon Supreme Court held in 1963 that the "main thrust" of their abortion statute was to prohibit "acts done intentionally to cause the death of the unborn child." 79 Likewise, Judge Thurman Arnold wrote in a District of Columbia case:

[I] $\mathrm{t}$ is apparent that abortion is generally regarded as heinous in character. In the great majority of the states it cannot be justified even to preserve the victim's health. Her life must be in danger . . . The performance of an abortion . . . is so offensive to our moral conception that it does not seem unjust to put on the defendant who has committed an abortion the burden of producing evidence that the act was justified on therapeutic grounds. ${ }^{80}$

No doubt social, moral, and philosophical judgments change. In 1968, for instance, the Therapeutic Abortion Act ${ }^{81}$ passed in California greatly expanded the priority of the mother's welfare. Such decisions are bound to be controversial, ${ }^{82}$ since they involve basic decisions about the protection of human life. But it is preferable that this kind of judgment be made in a forum which can best reflect the feelings and needs of the greatest number of persons in the society; judges should respect a decision so made. As Justice Tom C. Clark pointed out:

It is for the legislature to determine the proper balance, i.e., that point between prevention of conception and viability of the fetus which would give the State the compelling subordi-

7871 Cal. $2 \mathrm{~d}$ at -, 458 P.2d at 200, 80 Cal. Rptr. at 360.

79 State v. Elliott, 234 Ore. 522, 528, 383 P.2d 382, 385 (1963).

80 Williams v. United States, 138 F.2d 81, 83 (D.C. Cir. 1943).

81 CaL. Health \& SAFETy Code $\$ \S 25950-54$ (West Supp. 1968). Abortion is now permitted if "continuation of the pregnancy would gravely impair the physical or mental health of the mother," if the pregnancy resulted from incest or rape, or if the woman is under 15 years of age. Id. \$25951. It must be performed by a licensed physician at an accredited hospital, after approval by a committee of the medical staff of the hospital. Id.

82 See, e.g., N. Mietus, The Therapeutic Abortion Act-A Statement IN Opposition (1967); The CASE For Legalized Abortion Now 35-49 (A. Guttmacher ed. 1967) ; Louisell, Abortion, the Practice of Medicine and the Due Process of Law, 16 U.C.L.A.L. Rev. 233 (1969).

For an indication that there is presently support for the view that human life should still be protected after conception, see Greenhouse, Constitutional Question: Is There a Right to Abortion? N.Y. Times, Jan. 25, 1970, \$6 (Magazine), at 30, 90-91. 
nating interest so that it may regulate or prohibit abortion without violating the individual's constitutionally protected rights. ${ }^{83}$

\section{UnCONSTITUtional DeLEGation}

A third rationale was finally appended to the Belous decision. The court stated that the constitutional problems caused by the statute were further aggravated because: "The delegation of decision-making power to a directly involved individual violates the Fourteenth Amendment." 84 Although stated as a single issue, this problem is actually two-dimensional. The first aspect focuses on the individual to whom the power is delegated. According to this argument, a doctor has an interest in depriving a woman of her right to an abortion because his erroneous judgment could subject him to criminal prosecution and loss of his medical license. Therefore it is a deprivation of the woman's liberty without due process of law for him to decide the issue whether there is a need for the abortion.

As authority for this theory, the court cites Tumey $v$. Ohio. ${ }^{85}$ That case involved a mayor of a town whose responsibilities included trying criminal cases, and whose fees were derived from the fines imposed on the defendants he convicted. The Supreme Court held that this delegation violated the defendant's right to due process because the judge had "a direct, personal, substantial, pecuniary interest in reaching a conclusion against him in his case." 86

Two considerations detract from the applicability of Tumey to Dr. Belous's case. First, the doctor has a substantial countervailing incentive. While fear of prosecution may inhibit his willingness to perform an abortion, the immediate pecuniary interests, in combination with his personal sympathies, might on the other hand weigh in favor of operating. Considering the fact that the possibility of criminal prosecution and loss of practice is very rarely realized, ${ }^{87}$ there is no reason to believe that it would necessarily outweigh the possibility of pecuniary gain combined with sound professional and human judgment.

Second, there is a distinction between the practical effect of the decision made in Tumey and the decision of a doctor. One reason why a decision by an interested judge is obnoxious to the due process clause is probably that the defendant is bound thereby; this is not necessarily

83 Clark, Religion, Morality, and Abortion: A Constitutional Appraisal, 2 LoyouA U.L.A.L. REv. 1, 11 (1969).

8471 Cal. 2d at -, 458 P.2d at 206, 80 Cal. Rptr. at 366.

85273 U.S. 510 (1927).

$86 \mathrm{Id}$. at 523 .

87 The lack of enforcement was noted in 1868, H. Storer \& F. HEard, Crimmal ABORTION 136-147 (1868), and has continued to the present, see $L$. LADER, ABORTION 70-73 (1966); Ziff, Recent Abortion Law Reforms (Or Much Ado About Nothing), 60 J. CrIMr. L.C. \& P.S. 3, 8 (1969). 
true in the case of an abortion, for a woman can always continue to seek out a doctor who will not be afraid to act on the strength of his medical knowledge and judgment. Therefore, since the effect of the decision made by the doctor is considerably less severe, one should not apply to him the same due process standards developed for the behavior of judges.

Further, the more fundamental aspect of the delegation problem, which concerns the degree of power delegated, was unfortunately neither clearly differentiated nor adequately discussed by the court. Development of this issue raises further doubts about the court's conclusion. The right to an abortion was not deemed absolute; the court recognized that a valid state purpose could limit it. ${ }^{88}$ Accordingly, the issue should have been the method by which the legislature chose to apply restrictions. The California authorities cited by the court agree that legislative power may be delegated if there is "an ascertainable standard" 89 for its application; in those cases the authority to regulate industrial prices was delegated without a proper standard, which resulted in a power so arbitrary that it violated due process. Thus the heart of the matter is really vagueness. If the standard by which the doctor makes his decision is indeed ascertainable, as the court appeared to admit and as is contended above, ${ }^{90}$ delegation of that power is not unconstitutional.

\section{CoNCLUSION}

The Belous court may have been seeking, perhaps justly and with reason, to save the career of an eminent physician. However, if that was the court's motive, the judicial method used was perhaps not adequately tailored to it. It was surely not necessary to reach the constitutional issue in order to acquit Dr. Belous. As the court itself indicated, ${ }^{91}$ earlier decisions left room enough to find that the verdict was contrary to the weight of the evidence of the doctor's intent.

Moreover, there was good reason to act with judicial restraint, for the rationale of the Belous decision extends to more than just the statute before the court at that time. Not only does it threaten similar statutes which currently exist in thirty-seven states, ${ }^{92}$ but it also raises doubts about the constitutionality of the new Therapeutic Abortion Act ${ }^{93}$ in

8871 Cal. 2d at -, 458 P.2d at 200, 80 Cal. Rptr. at 360.

89 Blumenthal v. Board of Medical Examiners, 57 Cal. 2d 228, 235, 368 P.2d 101 , 104, 18 Cal. Rptr. 501, 504 (1962) ; State Bd. v. Thrift-D-Lux Cleaners, 40 Cal. 2d 436, 448, 254 P.2d 29, 36 (1953).

90 Text accompanying notes $13-31$ supra.

9171 Cal. $2 \mathrm{~d}$ at,- 458 P.2d at 198-99, 80 Cal. Rptr. at 358-59.

92 For a state-by-state listing of current abortion statutes, see H. Ziff, Recent Abortion Law Reforms (Or Much Ado About Nothing), 60 J. CRIM. L.C. \& P.S. 3, 3-4 (1969).

83 Cal. Health \& Safety Code $\$ \$ 25950-54$ (West Supp. 1968). See note 81 supra. A lower California court recently found this act unconstitutional. People v. Robb, No. 149005 (Cal. Orange County Mun. Ct., Jan. 9, 1970). 
California. That statute was not, of course, before the court, but it appears that even its clarifying features will not save it if it is no longer rationally related to an end which the state may properly seek to achieve. If the court believes that medical safety no longer justifies restrictions on hospital abortions during the first four months of pregnancy, ${ }^{94}$ and that the abortion statute recognizes no right to life of the foetus, ${ }^{95}$ then on what grounds can a woman ever be restrained from exercising her "right to an abortion"?

It is unclear how strongly the court relied on this purported "right to an abortion." The void-for-vagueness rationale would be superfluous if the statute were an invalid exercise of the police power. But the court, perhaps reluctant to commit itself fully to either argument, carefully intertwined the two. Until the court further clarifies the extent of the right to bear children, the future of abortion law in California is uncertain.

Jane Lang McGrew

9471 Cal. 2d at -, 458 P.2d at 200-02, 80 Cal. Rptr. at 360-62.

95 Id. at -, 458 P.2d at 203, 80 Cal. Rptr. at 363 . 